\title{
Factor Influencing Integrated Marketing Communication towards SME's Business Performance in Malaysia
}

\section{Masri Bin Abdul Lasi, Riduwan Bin Rahim}

To Link this Article: http://dx.doi.org/10.6007/IJARBSS/v11-i1/7842
DOI:10.6007/IJARBSS/v11-i1/7842

Received: 10 December 2020, Revised: 03 January 2021, Accepted: 15 January 2021

Published Online: 28 January 2021

In-Text Citation: (Abdul Lasi \& Rahim, 2021)

To Cite this Article: Abdul Lasi, M. B., Rahim, B. R. (2021). Factor Influencing Integrated Marketing Communication towards SME's Business Performance in Malaysia. International Journal of Academic Research in Business and Social Sciences, 11(1), 709-722.

\section{Copyright: (c) 2021 The Author(s)}

Published by Human Resource Management Academic Research Society (www.hrmars.com)

This article is published under the Creative Commons Attribution (CC BY 4.0) license. Anyone may reproduce, distribute, translate and create derivative works of this article (for both commercial and non-commercial purposes), subject to full attribution to the original publication and authors. The full terms of this license may be seen at: http://creativecommons.org/licences/by/4.0/legalcode

Vol. 11, No. 1, 2021, Pg. 709 - 722

Full Terms \& Conditions of access and use can be found at http://hrmars.com/index.php/pages/detail/publication-ethics 


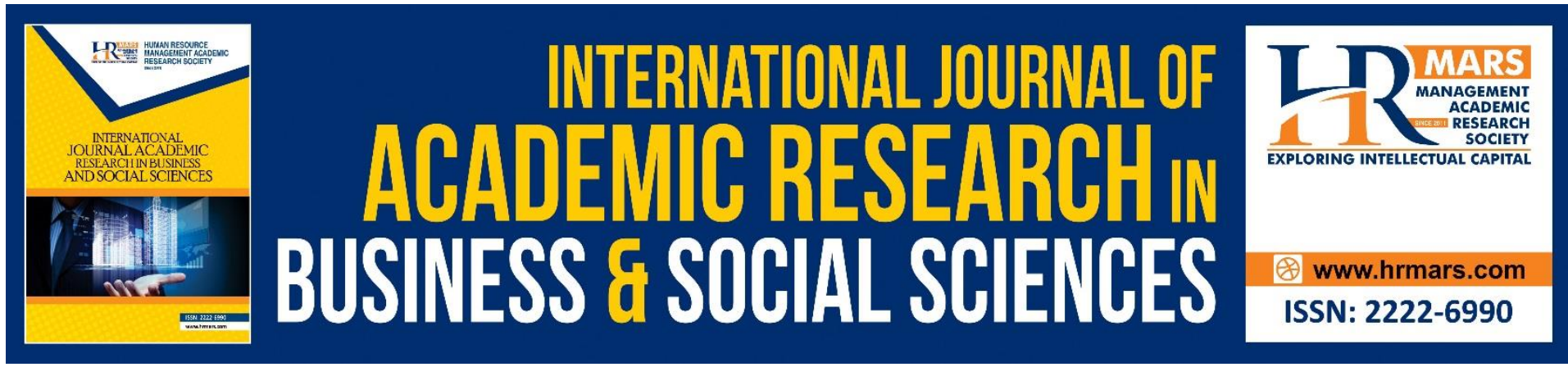

\title{
Factor Influencing Integrated Marketing Communication towards SME's Business Performance in Malaysia
}

\author{
Masri Bin Abdul Lasi ${ }^{1}$, Riduwan Bin Rahim² \\ ${ }^{1}$ Faculty of Business, City University Malaysia, ${ }^{2}$ City Graduate School, City University, \\ Malaysia
}

\begin{abstract}
Introduction: The motivation behind this stud is to explore the business procedure and execution in Small and Medium-Sized Enterprises (SMEs). The study zeroed in on SME's a result of the significance of SME's in the economy and the high level of them in the Malaysian business population. The current study inspected the connection between the coordinated integrated communication (for example Market-driving vision, Organizational Collaboration, Marketing Learning, Information Technology Resources and Market Turbulence) and SME's business performance.
\end{abstract}

Methodology: This study used a survey methodology, then analysed by using a descriptive analysis, correlation and regression analysis.

Findings: The outcome uncovered that variables had blended outcomes on SME's business achievement that lone marketing turbulences been accepted, though market-driving vision, marketing learning, information technology resources and organization collaboration came about the hypothesis been dismissed.

Conclusions/and Recommendations: This study gave significant commitments to professionals in creating approaches and procedures for business accomplishment among SME's in Malaysia.

Keywords: Business Performance, Integrated Marketing Communication, SME's

Introduction

SMEs represented $99 \%$ of all organizations over the Organization for Economic Co-activity and Development (OECD) nations and contributed between $50-60 \%$ of significant worth included. Commonly, SMEs work in administrations division with lower section expenses and asset necessities, especially discount and retail exchange and development. There are generally less SMEs in assembling area, prominently those that are capital or information escalated, requiring a bigger size of creation. Zafirah and Masri (2020) highlighted that, In Malaysia a systemic quality control for small businesses, which can be assessed in terms of specifications of the ISO 9001 quality standard or model framework of excellence, is not endorsed if you do not in most cases have high levels of low sophistication for enterprises. 
Regarding worldwide economic situation of SMEs and enterprise, consistent improvement has been seen since the $2008 / 2009$ monetary emergency, primarily determined by worldwide speculations and a bounce back in business certainty. Regardless of late indications of fixing, bank loaning to SMEs has been expanding at a moderate pace across nations reflecting lower interest for conventional bank financing by SMEs that have re-established their net revenues, inner financing limit and improved the business profiles to pull in elective financing sources. Simultaneously, challenges in getting to fund persevere for microenterprises, new companies and imaginative endeavours with novel plans of action.

This paper endeavours to examine the consistence of SME practice with integrated marketing communication correspondence hypothetical methodology for example market-driving vision, organization learning, marketing learning, information technology resources and market turbulence. In moving the examination field to SME together break down the various components of incorporation of marketing communication, exercises, hierarchical cycle and objectives.

\section{Literature Review}

The literature review was reviewed relating to the construct of the study and the relationship between integrated marketing communication i.e. market-driving vision, organizational collaboration, marketing learning, information technology resources and market turbulence with business performance of which the research gap was identified with five (5) research hypothesis.

Small and Medium Enterprises in Malaysia

SMEs are portrayed as the substances with the quantity of faculty fall underneath to a specific limit or other models, for example, by size, resource, deals turnover, and settled up capital (Chin and Lim, 2018). In Malaysia, SMEs are classified into administration or assembling area. For assembling division, SMEs are accumulated into three sorts of size which are smaller than usual (laborers under 5 and arrangements turnover of under RM300, 000); little (5 to 75 delegates with less turnover from RM300, 000 to under RM15 million) and medium (agents from 75 to 200 with bargains turnover of RM15 million to not outperforming RM50 million). At that point, the organizations and various territories are depicted as components with bargains turnover not outperforming RM20 million or full-time agents not outperforming 75 workers. Therefore, if SMEs are to achieve their goals efficiently, they must change traditional management concepts and adapt the concepts of modern management. Zafirah and Masri (2020)

\section{Business Performance}

The business performance has been generally analysed by researchers. Researchers have considered various factors which have sway business performance. They found that there are numerous factors which impact business performance, for example, entrepreneurial orientation (Wales, Parida, Patel, 2013; Alegre, Chiva, 2013), information technology (Chae, Koh, Prybutok, 2014) procedure and different factors. Regardless of whether there are different factors affecting business performance, authority style and inventiveness factors effect sly affect business execution.

Since pioneers have imperative effects over association procedures and innovativeness is crucial effect on genuine condition. After competition has become a weight contraption for 
associations wherever on over the world, the subjects of creativity and advancement have raised its place rapidly and these thoughts have ensured about their circumstance inside the degree of business strategies. Additionally, this there is brooder composing which has examined with association among imagination and execution. Rubera and Kirca (2012) have highlighted the relationship on firm inventiveness and execution for meta-informative confirmation. As demonstrated by the study, firm innovativeness in an indirect way impacts firm a motivator through its ramifications for market position and money related position.

Integrated Marketing Communication.

Since its origin in the mid-1990s, incorporated integrated marketing communication (IMC) has picked up prevalence among the two scholastics and specialists [Taylor, 2010a; Laurie and Mortimer, 2011; Association of National Advertisers (ANA), 2011], and research here is in crescendo (Kliatchko, 2008a, 2008b; Schultz et al., 2014; Muñoz-Leiva et al., 2015). Masri and Sallina (2020), defined that Integrated marketing communication is a strategic business method used for preparation, developing, executing, assessing, evaluating, organizing and convincing brand communication strategies with buyers, customers, prospective clients, suppliers and all other stakeholders in the organization. While this idea has been deciphered diversely and its hypothetical position is to some degree obscure, Tafesse and Kitchen (2016) have called attention to that most of the surviving writing has arrived at an agreement in its thought of IMC as an important methodology.

In any case, IMC is still under-investigated (Ots and Nyilasy, 2015) and the restricted observational proof supporting positive outcomes got from its execution stays a hindrance compelling practice and more extensive acknowledgment in meeting rooms. Masri and Tan (2020) suggested that, the researcher can emphasis more on the Integrated Marketing Communication (IMC) such as direct selling, mobile marketing, social media marketing, sales promotion and others, to investigate its role to build strong relationship with customers.

Hence, the hypothesis of the study as follows:-

$\mathrm{H}_{1}$ :- Marketing turbulence positively affect business performance.

$\mathrm{H}_{2}$ :- Market-driving vision positively affect business performance.

$\mathrm{H}_{3}$ :- Marketing learning positively affect business performance.

$\mathrm{H}_{4}$ :- Information technology resources positively affect business performance.

$\mathrm{H}_{5}$ :- Organization collaboration positively affect business performance.

\section{Research Methodology}

Research is a step-by-step procedure to provide a better comprehension of a problem or issue by collecting and analysing info and acquiring knowledge (Creswell, 2012; Matthews \& Ross, 2010; Paniel, 2015). Research design is a work plan which includes the complete methodology in detail to make sure the collected data can accurately answer the research questions. As mentioned by Sekaran (2003), employing the correct approach will significantly strengthen the value of the research outcomes. Sekaran and Bougie's (2016) research model described the causal relationship amongst variables instead of describing variables as either cause or effect whereby the cause is the independent variable while the direction of the effect (dependent variable) can be either be positive or negative in nature.

Therefore, to draw a powerful and convincing conclusion with the ability to answer the 
research questions, the research design should be planned according to the research problem, questions, objectives, and hypotheses. Based on the research objectives, this study intends to determine the factors influencing integrated marketing communication toward business performance in SME's in Malaysia. Therefore, this study is a causal research that looking for in testing cause-and-effect relationship between variables.

Target survey is entrepreneur's owners and highest managers in SME's companies. The main reason for the researcher to choose owners or managers or management over other companies is because these types of people need to be vigilant and familiar with the overall performances and activities of their company. A manager or owner can always be defined as having a vision and ability to manage it. Therefore, top management has the ability to better view and evaluate their firm, and they need to be aware of their organization in terms of decision-making, operations, performances and employee relationships (Barry 2008).

\section{Data Analysis and Findings}

The data collection that was done through the survey method, which is using the questionnaire that involved 225 respondents, is to increase the probabilities of collecting the data. The total response rate recorded is $1.05 \%$. The distribution of questionnaires was randomly based to SME business based in Kuala Lumpur that represent a total population of 21,344 SME's. Overall response rate is $1.05 \%$ of the 225 questionnaires distributed.

Background of the respondents is the initial part of the conduct surveys through survey forms. Through the background of the respondents, researchers can see more detail of all aspects such as gender, age, highest level of education, marital status, and position in the company, company's establishment, total employees, types of ownership and type of industry. The purpose to obtain the profile of the respondents is to ensure the equal representation in the stud by using SPSS version 23.0. The following is an analysis of respondents' background made overall in the test frequency through the test SPSS version 23.0.

The total number of respondents is 225 SME's in Kuala Lumpur, and percentage of male is $84.0 \%$ and $16.0 \%$ were female and showing the highest rate for male in SME's. The highest age recorded is $31-40$ years forming $56.9 \%$, followed by $24.9 \%$ respondents from age $25-30$ years, then, $10.7 \%$ from age $41-50$ and lastly is $7.7 \%$ from respondents age from age 51 years old and above.

For company's establishment, the highest ranking is above 16 years which represent $35.1 \%$, followed by SME below y years 30.7\%, 6 to 10 years $17.3 \%$ and 11 to 15 years $16.9 \%$. For total employees that SME have is represent $41.3 \%$ by above 151 staffs, followed by below 20 staffs $34.2 \%, 21$ to 50 staffs $12.0 \%, 101$ staffs to 150 staffs $7.1 \%$ and 51 to 100 staff $5.3 \%$. For types of ownership the highest ranking represent $41.3 \%$ is sole proprietorship, followed by partnership $33.3 \%$ and private limited (sdn bhd) $25.3 \%$.

As to identify the reliability of the items measure, the reliability analysis is done. Based on the result of the test for dependent variable and independent variables, the requirements of Cronbach Alpha must more than 0.7 and acceptable to conduct the research (Salkin, 2009). The Cronbanch Alpha value is within the range of 0.8 and 0.9 is very good and acceptable for conduct the research (Salkin, 2009). If the reliability of the Cronbach Alpha smaller than 0.6 
the valued is poor (Salkin, 2009). Table 4 is the summary of reliability results. Thus, the Cronbach Alpha for this study are business performance; .879, marketing turbulences; .902, market-driving vision; .896, market learning; .907, information technology resources; .932 and organization collaboration; .897.

Further, the descriptive investigation is to recognize the general scope of answer for each construct and assists with clarifying the attributes of the respondents in this research. The reactions that got in this investigation recorded 1.00 in the base reaction and 5.0 in the greatest estimation of reaction in this examination. Other than that, the estimation of mean were measure on a five Likert scale, which implies the higher number on the five point scale, will be more higher the integrity of the variable. On the off chance that the appropriate response is closer to five, will give a positive answer, and if the appropriate response near zero mirrors a negative idea from the respondents. What's more, if the estimation of mean is more than 4 shows a high arrangement, under 2 were considered as low understanding and mean estimation of 3 was considered as a moderate understanding. In this examination, the most noteworthy estimation of mean is 3.9441 for data innovation assets and the least worth is at 3.8009 which is business performance. Table underneath introduced a descriptive analysis in this research.

Table 1: Descriptive Analysis

\begin{tabular}{|l|l|l|l|l|l|}
\hline Variables $(\mathrm{n}=412)$ & $\mathrm{N}$ & Minimum & Maximum & Mean & Std. Deviation \\
\cline { 2 - 6 } & Statistic & Statistic & Statistic & Statistic & Statistic \\
\hline $\begin{array}{l}\text { Business } \\
\text { Performance }\end{array}$ & 225 & 2.20 & 5.00 & 3.8009 & .73497 \\
\hline $\begin{array}{l}\text { Marketing } \\
\text { Turbulences }\end{array}$ & 225 & 2.00 & 5.00 & 3.8770 & .72302 \\
\hline $\begin{array}{l}\text { Market driving } \\
\text { vision }\end{array}$ & 225 & 1.67 & 5.00 & 3.8467 & .72362 \\
\hline $\begin{array}{l}\text { Marketing Learning } \\
\text { Information } \\
\begin{array}{l}\text { Technology } \\
\text { Resources }\end{array}\end{array}$ & 225 & 2.00 & 5.00 & 3.8809 & .76160 \\
\hline $\begin{array}{l}\text { Organization } \\
\text { Collaboration }\end{array}$ & 225 & 2.00 & 5.00 & 3.9441 & .72816 \\
\hline
\end{tabular}

The correlation testing in this research was done to know the connection between the variables utilized. Mayers, Gamst and Guarine (2006) referenced the issues of multicollinearity and as per Cooper and Schindler (2003), no accurate level on building up the connection between the variables that have multicollinearity. They additionally contend the relationship of 0.80 or more may cause issues and propose a lower connection as good. In this examination, the connection between the factors will tried dependent on the rules by Guilford (1956). On the off chance that the connection is under .20 demonstrated as powerless relationship, .20 to .40 as a feeble relationship, .40 to .70 as moderate relationship and .70 to .90 as solid and more than .90 as solid relationship. Correlations not include the circumstances and logical results and just show how palatable the connection between the factors (Zikmund, 2003). 
Researcher utilized Pearson connection to test the goal in this examination to test the goal. Below table shows the relationship between all the variables in this investigation. The most elevated relationship coefficient is enrolled between business performance and marketing turbulences $.801^{* *}, \mathrm{p}<0.000$ followed by correlation coefficient between and least relationship is $.691^{* *}, p<0.000$ between business performance and marketing learning.

Table 2: Summary of Correlations

\begin{tabular}{|c|c|c|c|c|c|c|c|}
\hline & & BP & MT & MDV & $\mathrm{ML}$ & ITR & OC \\
\hline BP & $\begin{array}{l}\text { Pearson } \\
\text { Correlation } \\
\text { Sig. (2-tailed) } \\
\mathrm{N}\end{array}$ & 225 & $\begin{array}{l}.801^{* *} \\
.000 \\
225\end{array}$ & $\begin{array}{l}.760^{* *} \\
.000 \\
225\end{array}$ & $\begin{array}{l}.691^{* *} \\
.000 \\
225\end{array}$ & $\begin{array}{l}.706^{* *} \\
.000 \\
225\end{array}$ & $\begin{array}{l}.721^{* *} \\
.000 \\
225\end{array}$ \\
\hline $\mathrm{MT}$ & $\begin{array}{l}\text { Pearson } \\
\text { Correlation } \\
\text { Sig. (2-tailed) } \\
\mathrm{N}\end{array}$ & $\begin{array}{l}.801^{* *} \\
.000 \\
225\end{array}$ & $\begin{array}{l}1 \\
225\end{array}$ & $\begin{array}{l}.865^{* *} \\
.000 \\
225\end{array}$ & $\begin{array}{l}.808^{* *} \\
.000 \\
225\end{array}$ & $\begin{array}{l}.828^{* *} \\
.000 \\
225\end{array}$ & $\begin{array}{l}.784^{* *} \\
.000 \\
225\end{array}$ \\
\hline MDV & $\begin{array}{l}\text { Pearson } \\
\text { Correlation } \\
\text { Sig. (2-tailed) } \\
\mathrm{N} \\
\end{array}$ & $\begin{array}{l}.760^{* *} \\
.000 \\
225 \\
\end{array}$ & $\begin{array}{l}.865^{* *} \\
.000 \\
225 \\
\end{array}$ & 1 & $\begin{array}{l}.867^{* *} \\
.000 \\
225 \\
\end{array}$ & $\begin{array}{l}.843^{* *} \\
.000 \\
225 \\
\end{array}$ & $\begin{array}{l}.860^{* *} \\
.000 \\
225 \\
\end{array}$ \\
\hline $\mathrm{ML}$ & $\begin{array}{l}\text { Pearson } \\
\text { Correlation } \\
\text { Sig. (2-tailed) } \\
\mathrm{N}\end{array}$ & $\begin{array}{l}.691^{* *} \\
.000 \\
225 \\
\end{array}$ & $\begin{array}{l}.808^{* *} \\
.000 \\
225 \\
\end{array}$ & $\begin{array}{l}.867^{* *} \\
.000 \\
225 \\
\end{array}$ & 225 & $\begin{array}{l}.839^{* *} \\
.000 \\
225 \\
\end{array}$ & $\begin{array}{l}.828^{* *} \\
.000 \\
225 \\
\end{array}$ \\
\hline ITR & $\begin{array}{l}\text { Pearson } \\
\text { Correlation } \\
\text { Sig. (2-tailed) } \\
\mathrm{N}\end{array}$ & $\begin{array}{l}.706^{* *} \\
.000 \\
225\end{array}$ & $\begin{array}{l}.828^{* *} \\
.000 \\
225\end{array}$ & $\begin{array}{l}.843^{* *} \\
.000 \\
225\end{array}$ & $\begin{array}{l}.839^{* *} \\
.000 \\
225\end{array}$ & 225 & $\begin{array}{l}.816^{* *} \\
.000 \\
225\end{array}$ \\
\hline$O C$ & $\begin{array}{l}\text { Pearson } \\
\text { Correlation } \\
\text { Sig. (2-tailed) } \\
\mathrm{N}\end{array}$ & $\begin{array}{l}.721^{* *} \\
.000 \\
225\end{array}$ & $\begin{array}{l}.784^{* *} \\
.000 \\
225\end{array}$ & $\begin{array}{l}.860^{* *} \\
.000 \\
225\end{array}$ & $\begin{array}{l}.828^{* *} \\
.000 \\
225\end{array}$ & $\begin{array}{l}.816^{* *} \\
.000 \\
225\end{array}$ & 225 \\
\hline
\end{tabular}

**. Correlation is significant at the 0.01 level (2-tailed).

In order to determine the relationship between the dependent variable (business performance) and independent variables (marketing turbulences, market-driving vision, marketing learning, information technology resources and organization collaboration) to ensure these variables has a stronger or weaker relationship with the job performance. 
Table 3: Multiple Regression analysis of independent variable to dependent variable

\begin{tabular}{|l|l|l|}
\hline Independent Variables & Beta & Sig. \\
\hline Marketing Turbulences & .556 & .000 \\
\hline Market-driving Vision & .172 & .099 \\
\hline Marketing Learning & -.068 & .442 \\
\hline Information Technology Resources & -.001 & .989 \\
\hline Organization Collaboration & .194 & .020 \\
\hline
\end{tabular}

$* * P<0.01, R$ Square $=.669$

Thereafter, the summary of the hypothesis shows as follows: -

Table 4: Hypothesis

\begin{tabular}{|c|c|c|c|}
\hline & No & Hypothesis & Result \\
\hline $\mathrm{H}_{1}$ & & $\begin{array}{l}\text { Marketing turbulences affects business } \\
\text { performance. }\end{array}$ & Accepted \\
\hline $\mathrm{H}_{2}$ & & $\begin{array}{l}\text { Market-driving vision affects business } \\
\text { performance. }\end{array}$ & Rejected \\
\hline $\mathrm{H}_{3}$ & & $\begin{array}{l}\text { Marketing learning positively affects } \\
\text { business performance }\end{array}$ & Rejected \\
\hline $\mathrm{H}_{4}$ & & $\begin{array}{l}\text { Information technology resources affects } \\
\text { business performance }\end{array}$ & Rejected \\
\hline $\mathrm{H}_{5}$ & & $\begin{array}{l}\text { Organization collaboration affects business } \\
\text { performance }\end{array}$ & Rejected \\
\hline
\end{tabular}

\section{The Discussion}

Overall the relationship between marketing turbulence and business performance shows positively significant. In correlation result in table 4.6 indicates the hypothesis been accepted between marketing turbulence and business performance. Based on this result, it is shows that SME's that react on any changes in their industries that could affect their business performance.

As per Saridan and Mohamed (2012) has found that few components developed as profoundly affecting the achievement of these undertakings: the presence of key linkages with other private ventures, the lead of different advancements and the appropriation of in reverse coordination system. These equivalent components, nonetheless, were found to have no huge effect on the undertakings in the midst of serious rivalry. It's reflected that the marketing turbulences having significant role in ensuring SME's performance.

However, the relationship between market-driving vision and business performance registered not significant relationship. In correlation result in table 4.6 indicates the hypothesis been rejected between market-driving vision and business performance. Based on 
this, it's indicate that SME's not having properly set-up within their organization that resulted did not aware on the changes of their customer's need and want.

Alluding to Richard and Diane (2001) marketing driving vision can be depicted as a culture in which associations endeavour to make predominant incentive for their clients (and unrivalled performance for the business) by zeroing in on client needs and long haul gainfulness. While all organizations are unequivocally affected by their outside condition, little to medium estimated firms (SMEs) might be significantly more impacted by their own inward culture. The littler firms are not so much regulatory but rather more their very own impression explicit administration and inside conditions.

However, for this study, the independent variables did not significantly reflect to the SME's business performance that indicate that most of the SME's did not re-act on the changes either internally or externally.

In addition to the relationship between marketing learning and business performance registered not significant relationship. In correlation result in table 4.6 indicates the hypothesis been rejected between market-driving vision and business performance. Based on this, it's indicate that SME's did not re-act on any changes towards their industries.

As indicated by Porcu et al. (2016) referenced that better bits of knowledge into the impacts authoritative and pioneer qualities have on marketing learning can prompt more powerful advertising rehearses and furthermore the inward attributes of an association can assume a deciding function in executing an association wide marketing learning. It shows that the capacity to make and support the required hierarchical culture and asset foundation might be harder for SME's.

Looking forward on the relationship between information technology and business performance registered not significant relationship. In correlation result in table 4.6 indicates the hypothesis been rejected between information technology and business performance. Based on this, it's indicate that SME's did not upgrades the related information about their firm's based on the changes of the information technology.

In view of Tim Pett et al. (2010) that the capacity to utilize data information technology for business measure improvement, in the help of data gathering for better dynamic, and in any case upgrade of firm execution has for quite some time been the domain of huge firms. In any case, with declining costs, improved processing power, and quicker web network little and medium-sized endeavours (SMEs) might have the option to make and build up a compelling information technology competency. It shows that the important of the information technology that could reshape the performance of the SME's.

The relationship between organization collaboration and business performance registered not significant relationship. In correlation result in table 4.6 indicates the hypothesis been rejected between organization collaboration and business performance. Based on this, it's indicate that SME's did not communicate within the organizational regards to changes of the market whether internally or externally. 
As per Radziwon and Bogers (2018) that small and medium measured undertakings (SMEs) regularly participate involved with outside accomplices that supplement their exercises in improving their items and administrations so as to keep up their piece of the overall industry in a serious scene. Other than that the favourable circumstances offered by being installed inside territorial ecosystem system limits, for example, low exchange costs and decreased dangers of crafty practices, ecological open doors for outer information sourcing or increment of the range of authority. It shows that there is a difficulties, for example, low self-governance and authority over the accomplices and demonstrate shared issues and obligations critical for additional environment advancement for SME's in Malaysia.

\section{Limitation and Conclusion}

This study has limitation need to be face. The time is very limited to conduct this research for the whole SME's especially in Kuala Lumpur. The natures in policing career also have some difficulties to collect the data and to get some information. This is because, researcher need to follow their time and also schedule before meeting up. The main aim of this paper is to comprehensively review the connection between the market-driving vision, organizational collaboration, marketing learning, information technology resources, market turbulence and its impact on the business performance. In light of this research, it very well may be closed from the review of literature that the marketing turbulence is exceptionally connected with business performance. Modern vulnerabilities, by examination, identify with inputs utilized by the undertaking, rivalry and market, and ought to change across enterprises. Information vulnerabilities allude to the unconventionality in the procurement of satisfactory amounts and characteristics of creation inputs. Market vulnerabilities result from eccentric changes in the client condition, while serious vulnerabilities allude to the contender condition which envelops new contestants, industry contenders and item substitutes. Since mechanical vulnerabilities differ across enterprises, it is proper when the unit of analysis is an industry.

This research investigates intentionally oversaw shared information streams across hierarchical limits applied by SMEs that add to the advancement of the development of the ecosystem system they are drenched in. Besides, defining limits of productivity in the opportune spot could essentially expand open advancement exercises consequently emphatically affecting environment individuals' general presentation. Ecosystem system embeddedness could give an uncommon situation where, because of solid interdependencies, which diminish dangers of crafty practices, exchange expenses may fundamentally diminish for SME's to perform better in their ventures generally.

\section{References}

Abdul Lasi, B. M., \& Man, T. C. (2020). The Impact of Marketing Mix Elements on Brand Loyalty towards Speech Therapy in Health Science Industry Malaysia, American Journal of Industrial and Business Management, 10, 1575-1585.

Association of National Advertisers (2011), "Integrated marketing", Survey Research Report, 4th ed., ANA, Chicago, IL.

Balmer, J. M. T. (2001), "Corporate identity, corporate branding and corporate marketing seeing though the fog", European Journal of Marketing, Vol. 35 Nos 3/4, pp. 248-91.

Brodie, R. J., Coviello, N. E., Brookes, R. W., and Little, V. (1997), "Towards a paradigm shift in marketing?", Journal of Marketing Management, Vol. 13, pp. 383-406. 
Carson, D. (1990), “Some exploratory models for assessing small firms' marketing performance (a qualitative approach)", European Journal of Marketing, Vol. 24 No. 11, pp. 1-51.

Caywood, C., Schultz, D. and Wang, P. (1991), "Integrated marketing communications: a survey of national consumer goods advertising", Northwestern University Report, Northwestern University, Evanston, IL.

Chaston, I., and Mangles, T. (2002), Small Business Marketing Management, Palgrave, Basingstoke.

Chin, Y. W., Lim, E. S. (2018), SME Policies and Performance in Malaysia, https://www.researchgate.net/publication/326774817.

Chisnall, P. M. (2001), Marketing Research (6 $6^{\text {th }}$ ed.), Maidenhead: McGraw-Hill.

Churchill, G., and Lacobucci, D. (2004), Marketing research: methodological foundations (9th edition), Ohio: Thomson South-Western.

Cook, W. A. (2004), "IMC's Fuzzy picture: breakthrough or breakdown?", Journal of Advertising Research, Vol. 44 No. 1, pp. 1-2.

Cornelissen, J. P. (2003), "Change, continuity and progress: the concept of integrated marketing communications and marketing communications practice", Journal of Strategic Marketing, Vol. 11, pp. 217-34.

Cornelissen, J. P., and Lock, A. R. (2000), "Theoretical concept or management fashion? Examining the significance of IMC", Journal of Advertising Research, Vol. 40 No. 5, pp. 7-15.

Cornelissen, J. P., and Lock, A. R. (2001), "The appeal of integration: managing communications in modern organisations", Marketing Intelligence \& Planning, Vol. 19 No. 6, pp. 425-31.

Creswell, J. W. (2012). Educational research: Planning, conducting, and evaluating quantitative and qualitative research ( $4^{\text {th }}$ ed.), Boston: Pearson

Cromie, S. (1990), "The problems experienced by young firms", International Small Business Journal, Vol. 9 No. 3, pp. 43-61.

Delgado-Ballester, E., Navarro, A., and Sicilia, M. (2012), "Revitalising brands through communication messages: the role of brand familiarity", European Journal of Marketing, Vol. 46 Nos 1/2, pp. 31-51.

Duncan, T. R., and Everett, S. E. (1993), "Client perceptions of integrated marketing communication", Journal of Advertising Research, Vol. 33 No. 3, pp. 30-9.

Duncan, T. R., and Moriarty, S. (1997), "The IM audit: testing the fabric of integration", Integrated Marketing Communications Research Journal, Vol. 3 No. 1, pp. 3-10.

Ewing, M. T. (2009), "Integrated marketing communications measurement and evaluation", Journal of Marketing Communications, Vol. 15 Nos 2/3, pp. 103-117.

Fam, K. S. (2001), "Differing views and use of integrated marketing communications - findings from a survey of New Zealand small businesses", Journal of Small Business and Enterprise Development, Vol. 8 No. 3, pp. 205-14.

Gerbing, D. W., and Anderson, J. (1988), "An updated paradigm for scale development incorporating unidimensionality and its assessment", Journal of Marketing Research, Vol. 25, pp. 186-192.

Gilmore, A., Carson, D., and Grant, K. (2001), "SME marketing in practice", Marketing Intelligence \& Planning, Vol. 19 No. 1, pp. 6-11.

Hair, J. F., Ringle, C. M., \& Sarstedt, M. (2011). PLS-SEM: Indeed a silver bullet. Journal of Marketing Theory and Practice, 19(2), $139-151$. 
Hair, J. F., Bush, R. P., \& Ortinau, D. J. (2009). Marketing Research: In a digital information environment ( $4^{\text {th }}$ ed.), New York, NY: McGraw-Hill.

Hanafi, N. (2012), Business Performance of women owned SMEs in Malaysia: Learning and Entrepreneurial Orientations and the mediating roles of competitive advantage. DBA Thesis, UUM.

Hanny, N. N., Felix, T. M., Margaret, J. M., Nelson, O. N. (2010), Entrepreneurship: Its relationship with market orientation and learning orientation and its antecedents to innovation and customer value, Industrial Marketing Management 40 (2011), 336 - 345.

Keller, K. L. (2001), "Mastering the marketing communications mix: micro and macro perspective on integrated marketing communication programs", Journal of Marketing Management, Vol. 17, pp. 819-47.

Ken, M., John, T. M., Aysegul, O. (2002), The effect of entrepreneurial proclivity and maret orientation on business performance, Journal of Marketing, Vol. 66 (July 2002), 18 - 32.

Kotler, P., Wong, V., Saunders, J., and Armstrong, G. (2005), Principles of Marketing, 4th European ed., Pearson Education, Upper Saddle River, NJ.

Kliatchko, J. (2008a), "Towards a new definition of Integrated Marketing Communications (IMC)", International Journal of Advertising, Vol. 24 No. 1, pp. 313-348.

Kliatchko, J. (2008b), "Revisiting the IMC construct - a revised definition and four pillars", International Journal of Advertising, Vol. 27 No. 1, pp. 133-160.

Kliatchko, J., and Schultz, D.E. (2014), "Twenty years of IMC: a study of CEO and CMO perspectives in the Asia-Pacific region", International Journal of Advertising, Vol. 33 No. 2, pp. 373-390.

Kitchen, P. J., and Schultz, D. E. (1999), "A multi-country comparison of the drive for IMC", Journal of Advertising Research, Vol. 39 No. 1, pp. 21-38.

Kitchen, P. J., and Schultz, D. E. (1998), "IMC - a UK ad agency perspective", Journal of Marketing Management, Vol. 14 No. 5, pp. 465-85.

Kwaku, A. G., Ko, A. (2001), An empirical investigation of the effect of market orientation and entrepreneurship orientation alignment on product innovation. Organization Science, Vol. 12, No. 1, January - February 2001, pp $54-74$.

Laurie, S., and Mortimer, K. (2011), "'IMC is dead: long live IMC': academics 'versus practitioners' views", Journal of Marketing Management, Vol. 27 Nos 13/14, pp. 14641478.

Lee, D. H., and Park, C. W. (2007), "Conceptualization and measurement of multidimensionality of integrated marketing communications", Journal of Advertising Research, Vol. 47 No. 3, pp. 222-236.

Longenecker, J. G., Moore, C. W., and Petty, J. W. (2003), Small Business Management - An Entrepreneurial Emphasis, Thomson South-Western, Mason, $\mathrm{OH}$.

Low, G. S. (2000), "Correlates of integrated marketing communications", Journal of Advertising Research, Vol. 40 No. 1, pp. 27-39.

Malhotra, N. K. (2007). Marketing Research: An Applied Orientation. 5th ed., Upper Saddle River, NJ: Prentice-Hall.

Mathews, B., and Ross, L. (2010), Research methods a practical guide for the social sciences, Edinburgh Gate: Pearson Education limited.

Muñoz-Leiva, F., Porcu, L., and del Barrio-García, S. (2015), “Discovering prominent themes in integrated marketing communication research from 1991 to 2012: a co-word analytic approach", International Journal of Advertising, Vol. 34 No. 4, pp. 678-701. 
Nowak, G. J., and Phelps, J. (1994), "Conceptualizing the integrated marketing communications' phenomenon: an examination of its impact on advertising practices and its implications for advertising research", Journal of Current Issues \& Research in Advertising, Vol. 16 No. 1, pp. 49-66.

Ots, M., and Nyilasy, G. (2015), "Integrated marketing communications: why does it fail? An analysis of practitioner mental models exposes barriers of IMC implementation", Journal of Advertising Research, Vol. 55 No. 2, pp. 132-145.

Paniel, B. (2015). Research Design. Research Gate, Retrieved at: https://www.researchgate.net/publication/308262064.

Peltier, J. W., Schibrowsky, J. A.m and Schultz, D. E. (2003), "Interactive integrated marketing communication: combining the power of IMC, the new media and database marketing",International Journal of Advertising, Vol. 22 No. 1, pp. 93-115.

Phelps, J., and Johnson, E. (1996), "Entering the quagmire: examining the meaning of integrated marketing communications", Journal of Marketing Communications, Vol. 2 No. 3, pp. 159-72.

Porcu, L., Salvador, D. B. G. (2017), Measuring integrated marketing communication by taking a broad organisational approach. European Journal of Marketing, Vol. 51, No. 3, 2017, pp. $692-718$.

Preacher, K. J., \& Hayes, A. F. (2004). "SPSS and SAS procedures for estimating indirect effects in simple mediation models". Behavior Research Methods, Instruments, and Computers, 36, 717-731

Schultz, D. E., Tannenbaum, S. I., and Lauterborn, R. F. (1993), The New Marketing Paradigm: Integrated Marketing Communications, NTC Business Books, Lincolnwood, IL.

Schultz, D. E. (1999), "Integrated marketing communications and how it relates to traditional media advertising", in Jones, J.P. (Ed.), The Advertising Business: Operations, Creativity, Media Planning, Integrated Communications, Sage, London, pp. 325-38.

Schultz, D. E., Kim, I., and Kang, K. (2014), "Integrated marketing communication research", in Cheng, H. (Ed.), The Handbook of International Advertising Research, WileyBlackwell, Chichester.

Sirgy, M. J. (1998), Integrated Marketing Communications: A Systems Approach, PrenticeHall, Upper Saddle River, NJ.

Sekaran, U. (2000). Research Methods for Business: A Skill Building Approach (3rd Ed). New York: John Wiley \& Sons

Sekaran, U. (2003), Research methods for business: A skill building approach (4 $4^{\text {th }}$ ed.), New York, NY: John Wiley \& Sons, Inc.

Sekaran, U., \& Bougie, R. (2014). Research methods for business: a skill-building approach (6th ed.). Haddington: John Wiley \& Sons

Sekaran, U., \& Bougie, R. (2016). Research methods for business: a skill-building approach (7th ed.). Haddington: John Wiley \& Sons.

Tafesse, W., and Kitchen, P.J. (2016), "IMC - an integrative review", International Journal of Advertising, doi: www.tandfonline.com/doi/abs/10.1080/02650487.2015.1114168

Taylor, C. R. (2010a), "Integrated marketing communications in 2010 and beyond", International Journal of Advertising, Vol. 29 No. 2, pp. 161-164.

Wang, Y. J., Wu, C., and Yuan, J. (2009), "The role of integrated marketing communications (IMC) on heritage destination visitations", Journal of Quality Assurance in Hospitality and Tourism, Vol. 10 No. 3, pp. 218-231. 
Wright, J. S., and Flechter, A. D. (1981), "How do maximize your advertising investment", Journal of Advertising, Vol. 10 No. 2, p. 46.

Zahay, D., Peltier, J., Krishen, A. S., and Schultz, D. E. (2014), "Organizational processes for B2B services IMC data quality", Journal of Business and Industrial Marketing, Vol. 29 No. 1, pp. 63-74.

Zikmund, W. G., Babin, B. J., Carr, J. C., \& Griffin, M. (2010). Business research methods (8th ed.). Mason, HO: Cengage Learning 